\title{
E. 発生予察式ならびに今後の方向
}

\section{Forcasting Formulas and Prospective Problems}

\section{1. 発生予察式に関する問題}

\author{
奥 野 忠 一* \\ Tadakazu Окчмо: Problems in Preparation of Forecasting Formulas, with Special \\ Reference to Use of Electronic Computer
}

\section{（1）まえがき}

いもち病の発生予察式としては, 従来多くの場 合 飞, 次のような単回帰式が用いられている。

$$
y=a+b x
$$

ここに, $y$ は, 葉いもちまたは首いもちの発生程度あ るいは発生面積を表わす量であり，x としては特定期 間の気温雨量日照時間などの気象要素, イネの生育状 態を示す量, 分生胞子飛散数の上らな病原の発生程度 を示す量などがとられている。言らまでるなく，これ ら多数の $x$ の候補のなかからは, $y$ との相関が一番 高いものが選ばれる。このような予察式に伴う問題を 次にいくつかあげてみよう。

\section{a. 年数について （1）式の倸数を求めるため} の基礎になるデータは，普通 5 〜 10 年ぐらいのもの である。このような少数のデータからは, $y$ と $x$ との 間に，因果関係としては全く相関がない場合にも，計 算した相関係数の值 $r$ が 0.6 ぐらいになることはしば しば起こること，また 7 年のデータから $r=0.9$ と いう数值が得られても，その $95 \%$ 信頼区間は一定の前 提のもとでは 0.44〜0.98 であることなどは統計学の 教えるところである。それゆえ 5 〜 10 年のデータか ら相関係数の高い量を選んでも，他に裏付けになる証 拠が何もなければ，あまり信頼が扩けないといえる。

他方， 20 年， 30 年のデータをさかのぼつてとれ ば, イネの栽培条件, 病原の発現形態, 防除法の進歩 などのために，これらを単一の予察式を求めるための 基礎にするのは不適当であり，このことは多くの識者 の指摘するとおりである。この観点からすれば，現在 では 1955 年ごろ以降のデータしか用いられず，年数 はたかだか 10 年と見ざるを得ない。

\footnotetext{
b. 観測地点数について $y$ と $x$ とが, 法則と

* 農業技術研究所物理統計部
}

しての関連をもつものであるならば，その関係はいく つかの場所で普遍的に観察されるはずである。事実 6 月の気温が高ければ，また 6 月の日照時間が少ない と，葉いもちが增えるとよく言われる。したがつて， 僅か 10 年足らずのデータであつても, 同様のデータ がいもち病発生形態の相似た, いくつかの地点で得ら れているときには，これらをこみにして単一の信頼度 の高い予察式を得ることができるかもしれない。統計 的方法によつて現在何かをなし得るとすれば,こうす る外にはないであろう。

c. 総合予察について 単回帰式により, 常に安 定して高い推定精度を得ることは一般には困難であ る。そこで幾つかの気象要素を組合わせて重回帰式を 作るとか，イネ・病原の条件も加えて，いわゆる総合 予察をすることは適切な試みであろら。いずれの場合 にも $x_{1}, x_{2}, \cdots, x_{p}$ という既知のデータを用いて,

$$
y=a_{0}+a_{1} x_{1}+a_{2} x_{2}+\cdots+a_{p} x_{p}
$$

という重回帰式による推定をすることになる。係数 $a_{1}, a_{2}, \cdots, a_{p}$ を求めるための計算は, 現在では電子 計算機を用いて，きわめて迅速正確に行ならことがで きる。この場合には，いくつかの地点でのデータをこ みにしなければならないということの必要性は，一層 切実である。 $x_{1}, x_{2}, \cdots, x_{p}$ をそのまま用いるのでは なく, あらかじめ単一あるいは少数の「指数」に要約 したらえで, 回帰式を作ることも, その理論的根拠が 明らかであるならば，試みられてよい。

d. 逐次予察について 台風の進路予想が数時間 扣きに更新されるように，発生予察も発生時期が近づ くにつれて，たとえば 5 日扮きに，新しく得られた気 象データや病原の観測值を重回帰式の独立変数に逐次 加えて, 予察の精度を漸次高めていくことができる。

以上の諸点を実際の数值に基づいて検討し, 併せて 電子計算機の利用の可能性を確かめるために，次の計 
算を行なつた。この基礎データの蒐集選択は, 故古井 丸良雄技師（新潟県農業試験場）に負うものである。

\section{（2）電子計算機による計算結果}

a. データとその記号 1957〜1963年の 7 年間に, 新潟県内 16 郡で得られたデータを取上げ, 次の記号 で示す。

<データの種類 $>$

$$
\begin{aligned}
& x_{1}=\text { 葉い す ち発生面積 (甚) (10ha) } \\
& x_{2}=\text { " (多) (10ha) } \\
& x_{3}=\text { " (中十少) (100ha) } \\
& x_{0}=x_{1}+x_{2} \\
& y_{1}=\text { 首いも登生面積 } \\
& \text { (甚十多 } / 10+\text { 中 } / 100+\text { 少/1000) ( ha) } \\
& y_{2}=\text { 首いもち発生面積 } \\
& \text { (甚十多) } \cdot(10 \mathrm{ha}) \\
& t_{1}=5 \text { 月最低気温（各日最低気温の平均） } \\
& t_{2}=5 \text { 月気温低極（各日最低気温の最低） } \\
& t_{3}=5 \text { 月降水量 (計) }
\end{aligned}
$$

(以上 16 気象観測所の数值による)

$$
\begin{array}{ll}
u_{1}=6 \text { 月上旬平均気温 } & v_{1}=6 \text { 月上旬日照時間 } \\
u_{2}=6 \text { 月中旬 " } & v_{2}=6 \text { 月中旬 " } \\
u_{3}=6 \text { 月下旬 " } & v_{3}=6 \text { 月下旬 " } \\
u_{4}=7 \text { 月上旬 " } & v_{4}=7 \text { 月上旬 " } \\
u_{5}=7 \text { 月中旬 " } & v_{5}=7 \text { 月中旬 " } \\
u_{6}=7 \text { 月第 } 5 \text { 半旬” } & v_{6}=7 \text { 月第 } 5 \text { 半旬" } \\
u_{7}=7 \text { 月第 } 6 \text { 半旬" } & v_{7}=7 \text { 月第 } 6 \text { 半旬" } \\
u_{8}=8 \text { 月第 } 1 \text { 半旬" } & v_{8}=8 \text { 月第 } 1 \text { 半旬" } \\
u_{9}=8 \text { 月第 } 2 \text { 半旬" } & v_{9}=8 \text { 月第 } 2 \text { 半旬" }
\end{array}
$$

(以上 4 测候所の数值による)

\begin{tabular}{ll} 
<郡 & 名 $>$ \\
\hline \hline $\mathrm{P}_{1}=$ 東頸城郡 & $\mathrm{P}_{9}=$ 北蒲原郡 \\
$\mathrm{P}_{2}=$ 中頸城郡 (上越) & $\mathrm{P}_{10}=$ 中蒲原郡 \\
$\mathrm{P}_{3}=$ 西頸城郡 & $\mathrm{P}_{11}=$ 西蒲原郡 \\
$\mathrm{P}_{4}=$ 中 越 & $\mathrm{P}_{12}=$ 東蒲原郡 \\
$\mathrm{P}_{5}=$ 仜 羽 郡 & $\mathrm{P}_{13}=$ 南蒲原郡 \\
$\mathrm{P}_{6}=$ 中魚沼郡 & $\mathrm{P}_{14}=$ 岩 船 郡 \\
$\mathrm{P}_{7}=$ 南魚沼郡 & $\mathrm{P}_{15}=$ 新潟市 (下越) \\
$\mathrm{P}_{8}=$ 北魚沼郡 & $\mathrm{P}_{16}=$ 佐 渡 \\
\hline
\end{tabular}

\section{b. 葉いもち発生面積と気象要素との単相関係数}

第 1 表に, 葉いもち発生面積（甚十多） $x_{0}$ と, 各気象 要素との単相関係数を, 郡ごとに, $\mathrm{n}=7$ 年のデータ に基ついて計算した結果を示す。

このような特定の 7 年間のデータから求めた相関係 数に，2変量正規分布からのランダム抽出を前提とす る有意性検定を，無条件に適用すること自体には問題
があるが，一つの目印としてその $5 \%$ 抢よび $1 \%$ 有意 水準での $\boldsymbol{r}$ 值を示すと次のと拈りである。

$$
\begin{aligned}
& \mathrm{n}=7 \text { (自由度 } \mathrm{n}-2=5 \text { ）のとき } \\
& r=0.754(5 \%), 0.874(1 \%) \\
& \mathrm{n}=112 \text { (自由度 } \mathrm{n}-2=110) \text { のとき } \\
& r=0.187(5 \%), 0.244(1 \%) \\
& \text { 「郡内こみ」(自由度 } 95) \text { のとき } \\
& r=0.200(5 \%), 0.260(1 \%)
\end{aligned}
$$

ここで, $\mathrm{n}=112=7 \times 16$ とは, 16 郡, 各 7 年のデ 一タを一括して，一つの集団と考える場合にあたる。 また郡内こみとは, 各郡ごとに求めた相関係数を平均 した場合を指し，前者との違いは，各郡での平均発生 面積の違いが前者には含まれており，後者には含まれ ていない点である。したがつて, 平均発生面積が著し く異なる郡が存在しても，ある気象要素との相関がど の郡でも高ければ, 後者の「郡内こみ」では高い相関 が認められるが，前者のよらに全部のデータを一括す ると, 郡間の変動が関与して, 必ずしも高い相関係数 が得られるとは限らない。「郡内こみ」の計算は，「共 分散分析法」の手法を適用するため，その計算（電子 計算機に与えるプログラムも含めて）はそれだけ煩雑 になるが，以下すべてこの方法に依つた。

さて第 1 表から推論できることをまとめると，次の と拉り：

i ）「郡内こみ」の相関に注目すると，5月の最低 気温高く, 降水量多く, 6 月中旬の気温高く, 6 上. 中・下旬， 7 月中旬の日照時間が少なければ，葉いも らの発生が多くなることが認められる。しかし, 個々 の気象要素との相関はたかだか 0.4 までであつて，決 定的なものはないし，またこの推論は単相関係数だけ に基づいているのであるから，以上の諸条件の組合わ せが，葉いもちの発生を最も甚大にするともいいきれ ない。

ii）各郡ごとの相関係数をみると， 0.8 あるいは 0.9 を超えるものもときに現われているが，前節で述 べたようにこれに大きな信頼をおくことはできない。

\section{c. その他の単相関係数 首いもち発生面積 $y_{1}$,} $y_{2}$ と, 葉いもち発生面積 $x_{0}, x_{1}, x_{2}, x_{3}$ との単相関 係数を求めると，次のことがわかつた。

i )「郡内こみ」では，いずれの単相関も $0.3 \sim 0.5$ で $1 \%$ 有意水準を越え，その中では， $y_{1}$ (甚・多・中 ・少面積の加重平均) と， $x_{1}$ (甚) 拈よび $x_{3}$ (中十 少)との相関が高い。

ii）郡ごとに見ると， $\mathrm{P}_{5}, \mathrm{P}_{6}, \mathrm{P}_{13}$ では 0.9 あるい は 0.95 以上の高い相関があるが， $P_{3}, P_{4}$ では非常に 


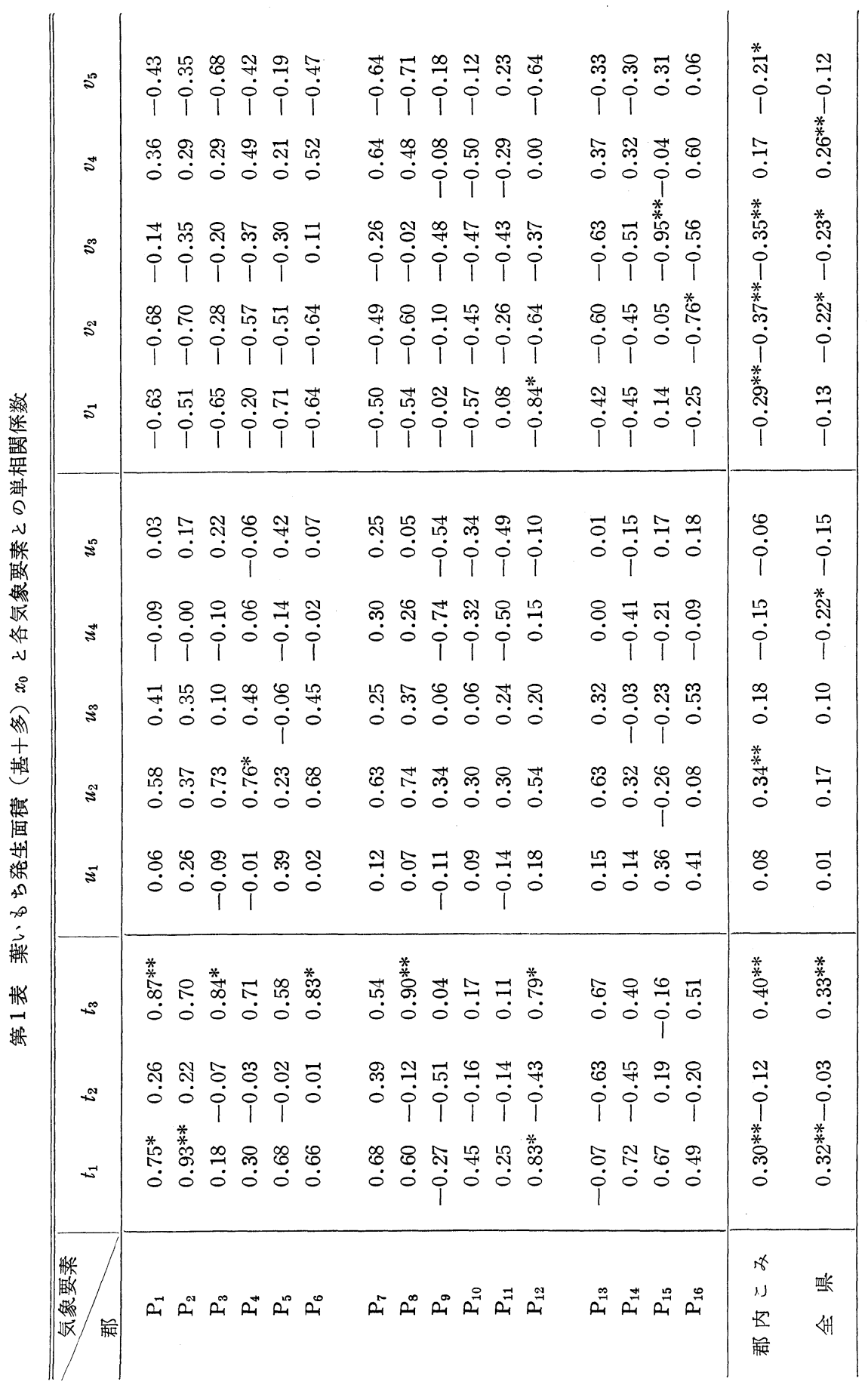


低い。これは前にも述べたように，これらの相関があ まり信頼できないためでもあるが，また常発地帯とほ とんど発生しない地带とのあることを暗示している。

首いもち発生面積 $y_{1}, y_{2}$ と各気象要素との単相関 倸数については, 次のように言える。

i ）「郡内こみ」では， 7 月第 $5 \cdot 6$ 半旬， 8 月第 $1 \cdot 2$ 半旬の平均気温, および 7 月第 5 . 6 半旬, 8 月 第 2 半旬の日照時間が $\quad 0.25 \sim 0.4$ の正の相関をもつ が，7月中旬の気温・日照とは添とんど相関がない。

ii）個々の郡ごとには，0.8 以上もの相関がたまに 現われるが，取上げて検討しなければならないような 傾向は認められない。

また，気象要素相互の間の単相関係数を，新潟地方 気象台, 長岡気象通報所, 高田・相川各測候所のデー 夕別に求めたが， $\mathrm{n}=7$ 年では，はつきりした規則性 は何も認められなかつた。

\section{d. 葉いもち発生面皘の予察式 葉いもち発生面} 積 (甚十多) (10ha単位) $x_{0}$ の, 種々の回帰式による 推定値を $\mathrm{X}_{0}$ で表わすと, 5 月末から発生時期までの 間に逐次求めた予察式(郡内こみ)は次のようになる： $<5$ 月末 $>$

( 5 月の気象要素のみを用いる) (重相関係数を $\mathrm{R}$ と $)$ $\mathrm{X}_{0}=26.57+10.85\left(t_{1}-11.24\right)$

$$
\mathrm{R}^{2}=0.0900, \mathrm{R}=0.30
$$

$\mathrm{X}_{0}=26.57+8.42\left(t_{1}-11.24\right)-1.68\left(t_{2}-3.71\right)$

$+0.163\left(t_{3}-119.6\right) \quad \mathrm{R}^{2}=0.2008, \mathrm{R}=0.45$ (4)

$<6$ 月 10 日 $>$ ( 6 月上旬の気温と日照が加わる)

$\mathrm{X}_{0}=26.57+6.68\left(t_{1}-11.24\right)-2.85\left(t_{2}-3.71\right)$

$+0.209\left(t_{3}-119.6\right)+3.59\left(u_{1}-18.52\right)$

$+0.109\left(v_{1}-53.8\right) \quad \mathrm{R}^{2}=0.2228, \mathrm{R}=0.47$ (5)

$<6$ 月20日 $>$ ( 6 月中旬の気温と日照が加わる)

$\mathrm{X}_{0}=26.57+5.85\left(t_{1}-11.24\right)-2.87\left(t_{2}-3.71\right)$

$+0.088\left(t_{3}-119.6\right)+3.13\left(u_{1}-18.52\right)$

$+0.077\left(v_{1}-53.8\right)+0.63\left(u_{2}-19.70\right)$

$-0.318\left(v_{2}-64.9\right) \quad \mathrm{R}^{2}=0.2563, \mathrm{R}=0.51$ (6)

$<6$ 月 30 日 $>$ ( 6 月下旬の気温・日照を加光る)

$\mathrm{X}_{0}=26.57-6.14\left(t_{1}-11.24\right)-1.70\left(t_{2}-3.71\right)$

$+0.035\left(t_{3}-119.6\right)+1.71\left(u_{1}-18.52\right)$

$-0.111\left(v_{1}-53.8\right)+8.89\left(u_{2}-19.70\right)$

$-0.495\left(v_{2}-64.9\right)+1.59\left(u_{3}-21.79\right)$

$-0.570\left(v_{3}-52.0\right) \quad \mathrm{R}^{2}=0.3905, \mathrm{R}=0.62(7)$

$<7$ 月 10 日 $>$ ( 7 月上旬の気温・日照を加える)

$\mathrm{X}_{0}=26.57-3.43\left(t_{1}-11.24\right)-1.16\left(t_{2}-3.71\right)$

$+0.074\left(t_{3}-119.6\right)+0.84\left(u_{1}-18.52\right)$

$-0.108\left(v_{1}-53.8\right)+3.12\left(u_{2}-19.70\right)$ $-0.491\left(v_{2}-64.9\right)+2.50\left(u_{3}-21.79\right)$

$-0.537\left(v_{3}-52.0\right)-5.43\left(u_{4}-23.51\right)$

$+0.507\left(v_{4}-43.4\right) \quad \mathrm{R}^{2}=0.4310, \mathrm{R}=0.66$ (8)

$<7$ 月 20 日 $>(7$ 月中旬の気温・日照を加える)

$\mathrm{X}_{0}=26.57-4.03\left(t_{1}-11.24\right)-1.17\left(t_{2}-3.71\right)$

$+0.020\left(t_{3}-119.6\right)+1.78\left(u_{1}-18.52\right)$

$-0.127\left(v_{1}-53.8\right)+0.32\left(u_{2}-19.70\right)$

$-0.551\left(v_{2}-64.9\right)+0.23\left(u_{3}-21.79\right)$

$-0.568\left(v_{3}-52.0\right)-6.10\left(u_{4}-23.51\right)$

$+0.781\left(v_{4}-43.4\right)-3.63\left(u_{5}-24.07\right)$

$-0.348\left(v_{5}-50.4\right) \quad \mathrm{R}^{2}=0.4456, \mathrm{R}=0.67$ (9) ここで, 常数項 26.57 は全県 7 年にわたる計 112 個 の $x_{0}$ の值の平均である。 $t_{1}, t_{2} \cdots$ から差引かれてい る常数 $11.24,3.71 \cdots$ も机艺れの変数 112 の個の值 の平均である。よつて, 上で得られる $\mathrm{X}_{0}$ は, $x_{0}$ の全 県平均值を推定していることになる。もし $\mathrm{P}_{2}$ 郡での 葉いもち発生面積 $x_{0}$ を予察したければ, これら 112 個のデータの平均の代りに, $\mathrm{P}_{2}$ 郡での 7 年の平均值 を入れればよい。たとえば，6月末での予察式 (7) は $\mathrm{P}_{2}$ 郡では次のようになる：

$$
\begin{aligned}
\mathrm{X}_{0}= & 32.57-6.14\left(t_{1}-11.2\right)-1.70\left(t_{2}-3.74\right) \\
& +0.035\left(t_{3}-113.7\right)+1.71\left(u_{1}-18.60\right) \\
& -0.111\left(v_{1}-50.3\right)+8.89\left(u_{2}-19.50\right) \\
& -0.495\left(v_{2}-63.4\right)+1.59\left(u_{3}-21.73\right) \\
& -0.570\left(v_{3}-47.4\right)
\end{aligned}
$$

他の郡でも全く同様であつて, 要するに郡内をこみに するときは, 偏回帰係数は 16 郡全部に共通に求める が，平均值はその郡の值を用いることになる。したが つて, これら 16 郡はいもち病発生形態の相似たいく つかのグループに分ける（これを層別といら）とこの 回帰式による推定の精度が高まるはずである，一方，

（9）式のような，13 もの変数に対する重回帰式を 求めるのは, 1 地点での $\mathrm{n}=7$ 年のデータからは不可 能でありここでのように，「郡内こみ」をしたから である。このときの回帰残差の自由度は, 「重共分散 分析法」によつて知られると拈り，112-16-13=83 もあるのである。これから必要ならばさらに変数の数 を增すことも，また一部の偏回帰係数を郡ごとに別々 に推定することも可能なことがわかる。

(3)〜（9)式を通覧して，次のことがいえる：

i） 5 月の最低気温 $t_{1}$ だけでは $\mathrm{R}=0.30$ しかない が，低極 $t_{2}$ と降水量 $t_{3}$ を加穴た重回帰式 (4) で は, 重相関倸数 $\mathrm{R}$ は 0.45 になる。こまかく吟味す ると，低極 $t_{2}$ はあまり利いていない。

ii） 6 月上・中旬の気温 $u_{1}, u_{2}$ と日照 $v_{1}, v_{2}$ が加 
わつても（式 (5), (6)), 予察の精度（普通 $\mathrm{R}^{2}$ で 評価する）は大して上がらない。

iii） 6 月下旬の気温 $u_{3}$ と日照 $v_{3}$ を加えると， $\mathrm{R}=0.62$ に上昇し，そのあと 7 月上中旬の気象要素を 加㝋ても，精度はほとんど改善されない。

iv) 式 (3)〜 (6) と式 (7)〜（9）では，それぞ れの中での共通の偏回帰係数は汪ぼ同じであるが，式

(6) から ( 7) へ移るときに, $u_{3}, v_{3}$ が導入される と,たとえば $t_{1}$ の係数は正から負に変る。これは, $t_{1}$ と $v_{3}$ との負の相関が大きく働くからであつて, 元 来 $t_{1}$ と $x_{0}$ との単相関は正であつたのが， $v_{3}$ といつ しよに考えるときは，その偏回㷌係数はかえつて負に なるのである。よつて，（7）式では次のようにいえ る。6月上・中・下旬の気温高く，日照少ないという 条件のもとでは, 5 月の気温低く, 降水量多いときの ほうが葉いもちが出やすいと。

\section{e. 首いもち発生面栍の予察式 首いもち発生面} 積 (甚十多/10+中/100+少/1000) (ha) $y_{1}$ の推定值を $Y_{1}$ で表わすと, 次のよらな予察式が逐次得られる。 〈葉いるち面積 (甚) $x_{1}$ だけから> $\mathrm{Y}_{1}=52.05+6.16\left(x_{1}-4.0\right)$

$$
\mathrm{R}^{2}=0.2227, \mathrm{R}=0.47 \text { (10) }
$$

$\mathrm{Y}_{1}=52.05+5.90\left(x_{1}-4.0\right)-0.067\left(x_{2}-22.6\right)$

$+1.200\left(x_{3}-48.3\right) \quad \mathrm{R}^{2}=0.2996, \mathrm{R}=0.55$ (11)

$<7$ 月第 6 半旬の気温と日照から>

$\mathrm{Y}_{1}=52.05+18.72\left(u_{7}-26.73\right)+0.320\left(v_{7}-48.2\right)$

$$
\mathrm{R}^{2}=0.1833, \mathrm{R}=0.43(12)
$$

$<7$ 月末での予察 $>$

$$
\begin{aligned}
\mathrm{Y}_{1}= & 52.05+5.41\left(x_{1}-4.0\right)-0.536\left(x_{2}-22.6\right) \\
& +0.695\left(x_{3}-48.3\right)-9.28\left(u_{4}-23.51\right) \\
& -0.536\left(v_{4}-43.4\right)-13.31\left(u_{5}-24.07\right) \\
& +0.693\left(v_{5}-50.4\right)+6.66\left(u_{6}-25.79\right) \\
& -1.620\left(v_{6}-32.0\right)+20.32\left(u_{7}-26.73\right) \\
& +0.395\left(v_{7}-48.2\right) \quad \mathrm{R}^{2}=0.3524, \mathrm{R}=0.59
\end{aligned}
$$

$<8$ 月10日での予察 $>$

$$
\begin{aligned}
\mathrm{Y}_{1}= & 52.05+4.18\left(x_{1}-4.0\right)-0.382\left(x_{2}-22.6\right) \\
& +1.078\left(x_{3}-48.3\right)-46.52\left(u_{4}-23.51\right) \\
& -1.026\left(v_{4}-43.4\right)+7.15\left(u_{5}-24.07\right) \\
& +0.318\left(v_{5}-50.4\right)-37.22\left(u_{6}-25.79\right) \\
& +0.759\left(v_{6}-32.0\right)+1.115\left(u_{7}-26.73\right) \\
& +4.518\left(v_{7}-48.2\right)+42.65\left(u_{8}-27.00\right) \\
& -2.951\left(v_{8}-45.8\right)-51.87\left(u_{9}-25.87\right) \\
& +7.640\left(v_{9}-36.19\right) \quad \mathrm{R}^{2}=0.3900, \mathrm{R}=0.62(14)
\end{aligned}
$$

これらの式の意味するところを要約すると，次のよ らになる。 i ）葉いもち面積（甚） $x_{1}$ だけでかなりの推定がで きる $(\mathrm{R}=0.47)$ が，（中十少） $x_{3}$ を加えると $\mathrm{R}=0.55$ になる。

\begin{tabular}{|c|c|c|c|c|c|}
\hline & I & 現 & $\begin{array}{l}\text { 值 } \\
\text { III }\end{array}$ & IV & 計 \\
\hline$\neq I$ & 35 & 3 & & & 38 \\
\hline 察 II & 14 & 18 & 2 & & 34 \\
\hline 值 III & 2 & 6 & 28 & 2 & 38 \\
\hline $\mathrm{X}_{0} \quad \mathrm{IV}$ & & & & 2 & 2 \\
\hline 計 & 51 & 27 & 30 & 4 & 112 \\
\hline
\end{tabular}

ii）ここにはあげなかつたが， 7 月上・中旬の気温 ・日照では首いもらの発生面積をほとんど予察できな いが，7月第 6 半旬の気温と日照だけを用いた（12）

\begin{tabular}{|c|c|c|}
\hline & 度数 & 同百分率 \\
\hline 的 中 & 83 & 74.1 \\
\hline 1 階級過大 & 20 & 17.9 \\
\hline 2 階級過大 & 2 & 1.8 \\
\hline 1 階級過小 & 7 & 6.2 \\
\hline 計 & 112 & 100.0 \\
\hline
\end{tabular}
式ではかなりの予察ができる。

iii）葉いもち面積と, 気温・日照のデータの両方を 用いた総合予察では， 7 月末で $\mathrm{R}=0.59 ， 8$ 月 5 日， 10 日となるにつれて $\mathrm{R}=0.60,0.62$ とごく僅かずつ 精度があがる。

f. 予察の的中率 以上では発生面積それ自身を 推定したが，実際の予察事業で知りたいのは，今年は 大発生か中発生か少発生かといらような大分類でよい のであろらから，各年の各郡での葉いもち発生面積 $x_{0}$ およびその推定值 $X_{0}$ をそれぞれ第 3 表の 4 階級に分 け，両者の連関表を作つてみた。

第 2 表-a 葉いるち予察の精度

ただし予察式は（9）を用いた。

第 2 表-b 同上の的中率

これより的中率は $74.1 \%$ ，これに，IをI， IIを IIIと予察するような 1 階級過大評価，あるいは，Iを IIIと予察するような 2 階級過大評価まで含めると，い わば安全率は $93.8 \%$ となり，過小評価は $6.2 \%$ とな る。

首いもち発生面積 $y_{1}$ (ha) について, 同様に I : 10 以下, II : $10 \sim 50$, III : 50 150, IV : 150 以上と して（14）式を用い的中率を求めると， $67.0 \%$ 安 
第 3 表 葉いも面積（甚十多）の 4 階級

\begin{tabular}{c|c}
\hline \hline 階級 & 面積 $(10$ ha単位 $)$ \\
\hline I & 10 以下 \\
II & $10 \sim 30$ \\
III & $30 \sim 100$ \\
IV & 100 以上 \\
\hline
\end{tabular}

全率では $91.1 \%$ であつた。

\section{（3）計算所要時間とプログラミング}

以上の計算には, 日本科学技術研修所電子計算機セ ンターの OKITAC 5090 C（沖電気製, 中型, 科学計 算用）を用いた。

i ） はじめにあげた, $x, y, t, u, v$ などの 27 変 数の相互の単相関係数 (全部で $27 \times 26 / 2=351$ 個あ る) の計算には， 1 郡 ( $\mathrm{n}=7$ 年) については, デー 夕読みこみ, 演算, 結果の印刷時間も含めて 2 分 26 秒を要したにすぎない。16 郡全部で約 39 分かかつ た。（この計算のために読みこまれた全部のデータ は,一たん磁気テープに記憶させた。)

ii）次に重回帰式を計算するために必要な变数を, それぞれ $\mathrm{n}=16 \times 7=112$ 個ずつ呼出し，「一元分類 データの重共分散分析」用のプログラム（作成者・農 研奥野千恵子技官）に従つて，「郡内こみ」のときの 偏回帰係数を求め, かつ 112 個の各実測值に 対する 回帰推定値, およびその両者の差を計算して印刷させ た。その所要時間は次のとおり

1 変数 (単回帰) のとき（式( 3 ), (10)) …2 分 5 秒 2 変数 (重回帰) のとき（式(12)）………2 分 20 秒 3 変数 (" ）のとき（式(4),(11))…2 分 38 秒 7 変数（"）のとき（式(6))……...4 分 50 秒 11変数（"）のとき（式( 8$),(13)) \cdots \cdots .8$ 分 0 秒 15変数（"）のとき（式(14)）……....20分 25 秒 もちろん, このプログラムが完成するまでには, デバ ッキング (しらみつぶし), プログラムのチェックに 数時間を要している。

\section{（4） 今後の問題点}

電子計算機を用いれば, 総合予察・逐次予察がきわ めて容易に行なえることは繰返すまでもないが，次の 諸問題が今後の研究に残されるであろう。

i ）観測地点の層别気象・土壌・栽培の諸要因 およびいもち病の発生形態を吟味して, 1 本の予察式 を適用しらる範囲をさめ，それによる地域区分をする
ことがきわめて重要である。積み重ねられたデータ と, 専門家の洞察力によつてのみ可能なしつかりした 地域区分の上に立つて初めて，上述のような計算も意 義をもつてくるであろう。各地域に含まれるべき観測 地点の数は, $\mathrm{n}=10$ 年のデータが使えるとして，回帰

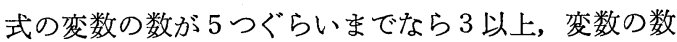
が 10 にもなるなら 4 地点以上あることが望ましい。

ii）変数の選択＼cjkstart計算がいくら容易になつたとは いえ, 予察に本質的には奇与しないデータまで含める と, 予測式を複雑にするばかりではなく, 結果の解釈 に混乱をもちこむことがある。それゆえ，因果関係の 追究から必要な变数が取上げられてくるのが，いちば ん望ましいが，試行錯誤法により変数の選択をするこ とも，電子計算機でやれるし，また多变量解析法や才 ペレーションズリサーチ的手法を援用してそれを行な らことも考えられる。

iii) 変数変換 式 (1) や (2) の回㷌式は, す ベて $x_{1}, x_{2}, \cdots \cdots \cdots x_{p}$ という変数の 1 次式で表わされ ている。元来, 相関係数は $y$ と $x$ との間に ( 1 次) 直線関係があるとさには意義のある量であるが，両者 の間の関係が複雑な関数で表わされるときには，その 関連の程度を表わすのに適さない。このような観点か らすると, いもち病発生率や降水量などの数字を, そ のままこれらの 1 次回帰式にもちこむには若干の疑問 がある。しかしながら，いもち病発生といらよらな複 雑な要因のからむ現象の真の姿を表わす関数式を求め ること自体, 容易ではないであろら。ただ,なるべく 直線関係に近づけるような, 適切な変数変換をさがす ことはやつてみる価値がある。

iv）質的分類値の採用 前段の变数变換をさらに 進めて，たとえば気温のデータを $20^{\circ} \mathrm{C}$ 以下， $20^{\circ} \sim$ $25^{\circ} \mathrm{C}, 25^{\circ} \mathrm{C}$ 以上という 3 階級に分類し, それぞれの 階級に属するデータを，たとえば $0 ， z ， 1$ （ただし Zは何らかの方法で推定する）に変換する。あるいは 単に $\mathrm{A}, \mathrm{B}, \mathrm{C}$ とする。こうして得られる分類值の取 扱いを研究することの利点は, 気温が $21^{\circ}$ でも $22^{\circ}$ でもいもちの発生に対する影響に違いはないが，ある 温度を超える日がつづくと大発生を招くというような ことがあるからである。しかし，この限界值を $29^{\circ}$ と するか $30^{\circ}$ とするかいらよらな点については，また 議論のわかれるところであつて，この困難は容易には 除去できない。したがつて差しあたりは，計量值のま まで取扱つて, 可能な限りの検討を試みるというのも 一つの接近法であろら。 
日植病報 XXXI，(記念号-2）：319～322 (1965)

\title{
2. いもち病発生予察の今後の方向
}

\author{
後 藤 和 夫*
}

Kazuo Gото : Some Prospective Problems in Forecasting System

いもち病発生予察按術について問題点を並べて，そ こから今後の方向を考壳てみたい。

\section{（1） いもち病発生予察の問題点}

\section{a. わが国の発生予察組織}

いもち病の発生予察に従事されている方々には方法 の上でも組織的にも種々不便や不満があることは察知 しているが，それにもかかわらず先輩の方々によつ て築かれた現在の組織は世界的なもので, 広く世界の 稲作国の技術者研究者間に注目を浴びていることは, 国際会議にしばしばその報告を求められたところから も推察できる。この組織は過去の食糧難時代に大きな 貢献をなし遂げたが，今後も当面している農業近代化 の流れの内で大きな責務を果たさなければならない。

\section{b. 発生予察による防除と防除暦による防除}

発生予察による防除は防除暦による平面的あるいは 静的な防除体系の上に打ち建てられた次元の高い動的 な防除体系である。これは一般論としていえることで 論議はいらないと思ら。

\section{c. 予察情報の必須余裕期間}

いもち病の発生予察は与兄られた場所の発生の時 期，量または程度を予察することであるが，予察の実 務としては単に事態発生前に判断できればよいのでは なく，その発現前にその判断を情報として伝達する時 間と伝達された情報をもとにした防除活動が間に合 い，かつ有効な防除が達成されるのに必須な時間（期 間) の余裕が要求される。

この必須余裕期間は発生予察事業の出発当初に比べ ると, その後の防除技術の進歩や関倸の社会施設の向 上によつてかなり短縮された。すなわち，（i 防除機 器は画期的に高能率となり（動力噴霧機もスズラン噴 ロだけだつたものから水平噴口の登場, またミスト散 布, 畦畔からの広幅散布, 人力や動力の散粉, 空中散 布などの実用化), (ii) 防除資材としての農薬も供給 は潤沢となり，(iii)その効力においては格段の進歩を 経てさらに前進を続けている（銅剤から有機水銀剤，

\footnotetext{
* 農林省農林水産技術会議
}

抗生物質剤や合成化学物質剤で予防力・治療力の色々 の段階のもの出現)。

このためにいもち病の予報には当初 10～15 日の必 須余裕期間を見ていたものが，現在ではその $2 / 3 \sim 1 / 2$ ぐらいでも間に合らほどに短縮されている。それだけ 予察業務上新しい資料が使用できるよらになり, 予察 を容易にしているわけであるが，この点はさら短縮の 努力が望まれる。

\section{d. 稲作型の複雑化と予察資料}

最近の 10 年余早期栽培の導入とともにわが国の稲 作は一般に早植になつたこと, 同一地区内に早期, 早 植, 普通期, 所によると晚期と異なる稲作型が混在し て複雑となり,このことはいもち病の発生予察を複雑 にし困難にしている。かかる複雑化に注意を払わない と予察資料報告も予察資料としての意義が薄らぐこと になる。たとえば今まで報告されていた初発の記録は 資料としての意味が著しく変化した。ここには異なる 作型に和忷る初発が必要なのか本田に特ける初発が重 視されるのか改めて検討を要するところがある。また この長期にわたる稲作期の漸変はいるち病発生相の漸 変を招来し，古い資料の活用には慎重な検討が必要な 実状になつている。加らるにこの間の把当者の交替は 古い予察資料の利用価值をさらに減殺している。

\section{e. 予察情報の経済性}

発生予察の目標は防除を有効的確ならしめるところ にあることは要綱に示されている通りであるが, 農業 構造改善の流れに沿つて発生予察情報は経済性が一層 重視されてこよう。具体的にはいもら病発生の時期, 程度 (量), それに色々な防除手段の 効率にかんがみ て, それら防除手段の活動に值いする事態が起こる見 込反であるかどうかを予察することが最も望をれよ ら。近年薬剤の進歩のためかなりの発生を見てから防 除活動に入る例も少なくない模様であるが，これでは すでにある程度損害が起こつてからの防除になつて, たとえ治療的効果にすぐれた薬剤を用いても効果はあ がりにくいので，一般には発生予察情報に基づいて予 防の手段にうつたえるのを原則とするのは今も昔も同 
ごである。この発生量の予察ははなはだ難かしいが,ま たはなはだ重要でもある。そしてこれには被害解析研 究がもつと進歩しなければならない。

\section{f. 地域による発生予察の難易}

いもち病の発生予察は䁔地は寒冷地よりも難かし い。そ机は寒冷地は夏の期間一杯を稲作に利用してお り，夏の高温による発病抑制は強くないため，いもち 病の発生環境は比較的単純で, 葉いもちから穗のいも ち病にまで一つづきに経過する。したがつて発病の状 況が個々の気象要因と単純に高い相関を示す例が多 い。しかるに暖地では夏の高温がいもち病の発生を強 く抑制するので, 田植から分けつ期中の発病期の後, 秋になつて再び発病好適環境が訪れるまでの間に別な 要因も入り込んだりして穂のいもち病発生にまざれが 多くなり，個々の気象要素との相関関係はあつても寒 冷地ほどに高くはならない例が多い。そこで暖地では 高い相関を求めて多因子を取り入れ色々な工夫をして 予察精度を高めようとしている例が散見される。予察 の精度を向上することは発生予察研究の一大命題であ るが，ここで見られたよらに，それには一般に多因子 による予察という方向があるものと考兄られる。

\section{g. 相関式による予察と理論の探究}

今までいもち病の予察式は各地で色々作られたが, これは相関関係としての把握が多く試みられ，環境条 件と発生との原因結果関係の追及に至らない例が多 w。

最近，気象庁の長期予報を伺ら機会を得た。その説 明飞执いて，以前には経験的飞帰納された色々な周期 をるとに解説された例を同つていたが，今回の説明に 捻いては気象を左右するものとして太陽の影響が大き いに違いないが，太陽活動の指標として黒点の消長を とり，これによつて従来より自信ある説明ができるよ うになつてきたとせられたのには深い感銘を受けた。 いもち病の発生予察にしてもやはり統計に基づく相関 值から一歩踏み出して，そこに関係が深いと思われる 事象を探し出して，これとの関係を解明することに努 め，その妥当性を検討する方向の努力がもつとなさる べきではないか。

\section{h. 発生予察方法の一貫した法則性の探究}

いもち病はいもち病菌とイネが水田という舞台の上 で行なら闘争現象なのである。したがつてその将来を 予察寸るには一応病原と作物と舞台環境に分けて検討 し，最後にこれらを総合して判断するのが便利であ る。筆者も発生予察二十周年記念誌の内にもこのよう そ書いた。
一般に多数の異なる種類の变数の上で現象を追究す るのは困難が大きいから，これを単純化することが望 ましいが，このためには一つの基本的な变数に変換し て議論ができるようになると都合がよい。まず舞台環 境の一つとして気象条件についてみるとわが国の夏は 高温のときは晴天（日照）が多く降雨は少ないなど相 互に関連を示すことが多いので，そのどれか一つで表 現しようとすれば何をどのように採り上げるべきであ ろらか。

一般に気象を支配するものは太陽からのェネルギー であるらが，そうすると日照が基準として最も近いか も乙れない。しかし気象は必ずしも局地的なェネルギ 一授受できまるわけでもなさそらであるから，いもち 病発生のような生物現象との関連を考えるとむしろ温 度が重視されるのではなかららか。事実各県の資料を 見たときに日照との関連が大きい例も少なくなかつた が，温度が高い相関を示した事例の注らが多かつた。 そこで温度を基準にし，その他の気象条件をとり入れ て, いもち病発生の難易についての気象環境関係式が できこれからそのときどきの発病難易に関する環境 指数のごときものが算出し得るのではなかららか（本 当は気象環境係に対する反応は品種，土壌などでも違 らので複雑ではあるが)。

次に病原の量に执いても研究を進めればある時期の 実測を基準にするなどにより，その後の增減を気象要 因，特に温度を基準とした別の気象環境関係式から推 算し得られるのではなかららか。

一体いもち病発生に直接関連をもつ病原量とはイネ との闘争の場に動員される活性の病原胞子量であるう から，その意味でスライド上に落下する胞子量でこれ を測ろらとする企ては確かに的に近い着想ではある。 これに比べると回転胞子採集器などで現に空気中に浮 遊している胞子量を測つて使らことは，いもち病発生 といら点からみるとスライド法より一歩手前の観測值 を利用するものである。だからスライド法がどちらか といえば局地性が強いのに比べて, 浮遊胞子数のほう はやや広い対象への利用に意義が大きいとされてい る。これをむら少し遡つて病原量の指標をその胞子が 生産される場の量や質や胞子形成環境なぞから推算す ることも不可能ではなさそうで，すでにこういう面の 各種研究も進んでいる。このようにして病原量推定值 む研究を進めれば前と同様に温度を主とする別の気象 環境関係式が作られ，周到に考慮をめぐらせばこの式 とある時点の調查資料とから次の時点の活性胞子動員 推定量が表現し得るのではないだろうか。 
イネについてみても人為的な栽培法変化といら点を 除けばある土地（または水田）のイネは気象要因が生 育やいもち病抵抗力などを性格づけるとみられないこ とはない。だからこういら意味でここにも別の気象関 係式が作り得るおけで，ある時点の調査をもとにして いもち病発生蔓延の可能性に関するなんらかの要約が 数式の形で書けることになるのではなかららか。そし てこれには人為的要因として品種の変化, 施肥量の増 減のごとき影響を別途計算補正することにすれば，イ ネについてもいもち病発生蔓延の可能性についての総 合的な一つの式に取りまとめることができるかと思わ れる。こうしてこれら病原, イネ, 発生環境を総合統 一することが希求されるが，本当はかかる式の組立や 究明がいもち病の生態研究の究極なのであるう。

な拉いもち病発生の上らな生物現象の基本的要因と してここでは温度を考えてみたが，もつとよい指標が 他に得られるなら温度に固執するものではない。また 上述の考觉から総合的な関係式が得られたにしても， その式は相当複雑なものになつて実際の計算は大変面 倒になるに違いない。しかし現状では関係式がはつき りすれば計算上の困難には対策がないわけではない。

\section{（2） いもち病発生予察の今後の方向}

以上述べたことから考えて今後注意すべき点として 次のように考光られる。

\section{a. 予察資料の客観性の確保}

発生予察は個人動作としては期待ができにくく, 組 織として動いて扣り,今後もこの点では同様であるが， (1)-d に述べたように同じく普通期稲作といつてもわ が国の田植期は約 10 年間に 1 週間から 1 旬くらいは 早まつている。そしてかかる栽培時期の変動が病害発 生相に大きく影響している事実を見せられてきた。

こういうわけで各種気象資料などをそのま統計的 研究に使うことは大きな疑問が投げられることになつ てきた。したがつて折角蓄積された予察資料はどうい ら稲作のらえで採られたかを面倒でも 1 年 1 年記録し て执いて頂く必要がある。殊に担当者に交替がある際 はこのことが非常に重要である。

\section{b. 調查手段や方法の簡易化}

発生予察は大きな組織として動いているので，たと え精緻でも繁雑なものは担当者に受けない。たとえば いもち菌の胞子数調査が使いにくかつた理由の一つは ぞうもその手段が多少面倒であつたものと感ぜられ る。胞子数調查は要するに病原量を表現しょうとする ものであるからここの目的のためには肉眼調査による
病斑の数, 大きさ, 活性, その発生位置のごときから ある指標值を構成することができないだろらか（長野 農試市川・原田（1962）は前述に似た指数をスライド 法胞子採集に併用すれば有用であるとの注意があつ た)。長野の当初の発生予察研究に当たつて穂いもち発 生に対して胞子飛散数は病葉率上りも著しく高い相関 を示すとなつているが，これは比較が病葉率というゃ や粗い調査資料によつたためではないか。とにかく組 織に上り多数の人を同じ方向の仕事に動かすには，そ れらの人々がやつてみ上うとの意欲がわくょらに簡易 でかつ説得力をもつ方法の開発がきわめて大切であ る。

\section{c. 予察組織の技術的能率化について}

いもち病発生予察は今までももちろん組織として動 いているのだが, 労力は高騰し世の中は忙しくなつて いるのであるから，方法を一層簡易化し，これを機珹 力に乗せて迅速に高能率にもつていく必要がある。

迅速に行なつている例として自分はかつて米国のオ ハイオ州のリンゴ黒星病の発生予察を見た。本病の発 生予察はヨーロッパの国々でも実施して抢り，その原 則はいずれも同様で, 越冬菌の子囊胞子成熟および放 出の状況とリンゴ樹の萠芽状況とその時期の気象の 3 要素から判断している。同州では中央で菌の成熟状沉 などを検査し，発病期になると時間をきめて州内重要 数個所との同時通話電話で各地の事情を報告し合い, 中央からは気象予報などの最新報知を入れるなどして 電話で会議し判断し，これが直らに各地方的予報にな る模様であつた。わが国では数か所の同時通話電話の 制度はまだないが，とにかく社会のあらゆる便益を利 用して迅速にことを運ぶ心構光は従来ももたれていた が大切である。またそれにはどうしても色々な仕事を 簡易化する努力が大切である。

組織化のもら一つの問題点はいもち病発生予察手段 の機械化である。いもち病の発生予察の要因をもし単 純化しようとすれば温度を基本とすべさではなからう かと前に述べたが，予察精度を高めよらとすれば，と り込采れる要因は多くなり，手続はいずれにせよ複雑 になり，それを計算するには大变な仕事になる可能性 がある。しかし実際には調查すべき観測值と計算方法 がきまれば，さきほど奥野技官のご説明があつた電子 計算機のような新鋭機械の力を借りることによつて迅 速に計算はできるはずである。したがつてこれには全 国を幾つかの地域に分けて計算センターをもち，ここ に電話かテレタイプのような手段で資料を送り，計算 結果の返事を受けるよらに組織することが考えられる 
のである。

しかしこれを組織立てる前には，どらいら因子をど のように計算すべきかといらごとき基礎的研究をもつ と積まなければならない。もちろん予察の全部を機械 化することは困難で, 最終的には担当者の判断に頼る ことになろらが, 当面複雑ないもら病発生予察方法を
どのようにして電子計算機の機能に乗せうるかが研究 上の重要課題である。このためには試験研究機関の研 究上の努力はもちろん大切であるが，植物防疫課など 本省側に拈いても予算上の十分な後楯が要請されると ころである。 